\title{
Effect of Dose and Application Site on Quinclorac Absorption BY BARNYARDGRASS BIOTYPES ${ }^{1}$
}

\author{
Efeito de Dose e Local de Aplicação na Absorção de Quinclorac em Biótipos de Capim-Arroz
}

\author{
CONCENÇO, G. ${ }^{2}$, SILVA, A.F. ${ }^{3}$, FERREIRA, E.A. ${ }^{4}$, GALON, L. ${ }^{4}$, NOLDIN, J.A. ${ }^{5}$, ASPIAZÚ, I. ${ }^{4}$, \\ FERREIRA, F.A. ${ }^{6}$ and SILVA, A.A. ${ }^{6}$
}

\begin{abstract}
This work aimed to evaluate the uptake and translocation of quinclorac in function of application sites (shoot or roots) by Echinochloa crusgalli biotypes resistant and susceptible to this herbicide. The treatments consisted of quinclorac doses $(0 ; 0.5 ; 1 ; 2 ; 4$; 16 and $64 \mathrm{ppm})$, applied on the shoot or roots of seedlings of barnyardgrass biotypes. The experimental units consisted of plastic cups containing $250 \mathrm{~cm}^{3}$ of sand. The treatments were applied 10 days after emergence, when barnyardgrass plants reached a 2- to 3- leaf growth stage. The barnyardgrass biotypes were irrigated with nutritive solution weekly and maintained for 40 days after emergence, when length, fresh and dry matter of shoot and roots were evaluated. Variance analysis was carried out using the F test at $5 \%$ probability, and in case of significance, a non-linear regression analysis was also carried out using a three-parameter logistic model. In the susceptible biotype, quinclorac was more absorbed by the roots than by the shoot. Comparing dry mass production of the different plant parts of the susceptible biotype per application site, it was verified that quinclorac action is higher when applied to the plant roots. However, for the resistant biotype, it was not possible to determine the dose causing $50 \%$ reduction in dry mass accumulation $\left(\mathrm{GR}_{50}\right)$ and in the resistance index (RI) between both biotypes, due to its high resistance to quinclorac (128 times the recommended dosage). The results showed that quinclorac resistance by the evaluated biotype is not due to differences in the absorption site, strongly suggesting that the resistance acquired by the biotype may result from alteration in the target site.
\end{abstract}

Keywords: herbicide, resistance mechanism, Echinochloa crusgalli.

RESUMO - Objetivou-se com este trabalho avaliar a absorção e a translocação do quinclorac em função dos locais de aplicação (parte aérea ou raiz) em biótipos de capim-arroz (Echinochloa crusgalli) resistente e suscetivel a esse herbicida. Os tratamentos foram compostos por doses de quinclorac (0; 0,5; 1; 2; 4; 16; e 64 ppm), aplicadas na parte aérea ou nas raizes das plântulas dos biótipos de capim-arroz resistente e suscetivel ao herbicida. As unidades experimentais foram compostas por copos plásticos contendo $250 \mathrm{~cm}^{3}$ de areia. Dez dias após a emergência aplicaram-se os tratamentos, com as plantas de capim-arroz em estádio de duas a três folhas completamente expandidas. Os biótipos de capim-arroz foram irrigados com solução nutritiva semanalmente e mantidos até 40 dias após a emergência, quando foram avaliados o comprimento e as massas fresca e seca da parte aérea e das raizes. A análise de variância foi realizada pelo teste F a 5\% de probabilidade e, em caso de significância, realizou-se análise de regressão não linear pelo modelo logístico de três parâmetros. No biótipo suscetivel, o quinclorac foi mais absorvido pelas raízes em relação à parte aérea. Comparando a produção de massa seca das diferentes partes da planta do biótipo suscetivel, por local de aplicação do herbicida, verificou-se que a ação do quinclorac é maior quando aplicado às raizes das plantas. Todavia, para o biótipo resistente, em razão da alta tolerância deste ao quinclorac (superior a 128 vezes a dose recomendada), não foi possivel determinar a dose que causa $50 \%$ de redução no acúmulo de massa seca $\left(G R_{50}\right)$ nem o

Recebido para publicação em 11.7.2008 e na forma revisada em 21.8.2009.

2 Engo-Agro ${ }^{-}$, D.Sc. em Fitotecnia, International Agronomist, Valmont Industries, <gconcenco@yahoo.com.br>; ${ }^{2}$ Doutorando do Dep. de Fitotecnia, Universidade Federal de Viçosa - DFT/UFV, 36570-000 Viçosa-MG; ${ }^{3}$ Pós-Doutorando do Dep. de Fitotecnia DFT/UFV; ${ }^{4}$ Engo-Agr ${ }^{\circ}$., Ph.D., Pesquisador da EPAGRI/EEI - Itajaí-SC; ${ }^{5}$ Prof., Dr., Dep. de Fitotecnia - DFT/UFV.

Planta Daninha, Viçosa-MG, v. 27, n. 3, p. 541-548, 2009 
indice de resistência (RI) entre ambos os biótipos. Os resultados desta pesquisa evidenciam que a resistência do biótipo avaliado ao quinclorac não se deve a diferenças em relação ao local de absorção e indicam que a resistência do biótipo avaliado ao quinclorac pode resultar de uma alteração no local de ação do herbicida na planta.

Palavras-chave: herbicida, mecanismo de resistência, Echinochloa crusgalli.

\section{INTRODUCTION}

Quinclorac is an auxinic herbicide belonging to the quinolinic acid class, with a wide spectrum of action, recommended for control of some broad leaf weeds and grass species in rice, corn, soybean and sorghum crops and pastures in several countries (Chism et al., 1991). In Brazil, quinclorac is registered only for control of barnyardgrass and junglerice (Echinochloa spp.) and jointvetch (Aeschynomene spp.) in irrigated rice crop (Andres et al., 2007), for both pre- and postemergence applications. The intoxication symptoms of the weeds by quinclorac occur between the seventh and tenth days after application in the form of dark red spots inducing chlorosis and, followed by plant death (Grossmann \& Kwiatkowski, 2000).

Although quinclorac is selective to relatively well-known species, its mode of action in weeds and mechanism of selectivity for crops are not completely understood. (Berghaus \& Wuerzer, 1987;Grossmann \& Kwiatkowski, 2000). However, Zheng \& Hall (2001) proposed that a group of proteins named ABP (auxin-binding proteins) is the site of the auxin-mimic herbicides. These authors characterized bio-chemically and physiologically the resistance of a Brassica kaber biotype to herbicides presenting this mode of action, finding no differences in the absorption, transport or metabolism of auxinmimic herbicides between the resistant and susceptible biotypes.

On the other hand, for the control of three populations of quinclorac-resistant Echinochloa crusgalli found in Spain, herbicide doses up to 6,10 , and 26 times higher than the susceptible biotype used as reference were necessary for a $50 \%$ mass accumulation reduction (López-Martínez et al., 1997). Abdallah et al. (2006), found a higher capacity of cyanide detoxification in the resistant biotype Digitaria ischaemum, with intensified production under quinclorac application. Also, Sunohara \& Matsumoto (1997) reported that the effects of quinclorac application to corn plant leaves differ from the symptoms observed with the application of other auxin mimetizers. Grossmann \& Kwiatkowski (2000) concluded that quinclorac application to the roots of grass species reduced dry mass accumulation in the aerial part. In another work, quinclorac did not inhibit cellulose biosynthesis in roots of plants treated with the herbicide (Tresch \& Grossmann, 2003).

The tolerance of some species to quinclorac is due to smaller herbicide exportation out of the treated leaf (Zawierucha \& Penner, 2000). Chism et al. (1991) determined that quinclorac metabolism is not involved in the mechanism of crop selectivity, but translocation and exudation of the intact product through the roots may be involved. Thus, the site of action of the herbicides in barnyard grass susceptible or resistant biotypes may be a factor that makes this species resistant to quinclorac.

This work aimed to evaluate the absorption and translocation of the herbicide quinclorac in function of the sites of application (shoot or roots) by barnyard grass biotypes resistant and susceptible to this herbicide.

\section{MATERIAL AND METHODS}

The trial was conducted under greenhouse at the Universidade Federal de Viçosa, in Viçosa-MG, Brazil, with controlled irrigation. The treatments consisted of quinclorac concentrations $(0 ; 0.5 ; 1 ; 2 ; 4 ; 16$ and $64 \mathrm{ppm}$ ) applied to the shoot or roots of the barnyardgrass biotypes resistant and susceptible to this herbicide, ten days after emergence. Barnyardgrass seeds were sown in plastic cups containing $250 \mathrm{~cm}^{3}$ of sand, 
leaving only one plant per vase after thinning. To guarantee the good development of the plants, fertilizer containing macro and micronutrients was applied when the plants were on the 2- or 3-leaf stage. This operation was repeated weekly until harvest at 30 days after application of the treatments. The experiment was arranged in a completely randomized design with 4 replications.

The experimental units were maintained in individual plastic trays, containing $1.0 \mathrm{~cm}$ of water below the sand level, throughout the experiment. The treatment applications were performed ten days after emergence, with the barnyardgrass plants at the 2- to 3- completely expanded leaf stage. For shoot application, the experimental unit sand was completely covered with a paper towel layer to avoid contact with the herbicide solution. The product was applied to the leaves with cotton soaked in the solution to provide total and homogenous coverage of all the plant's shoots. For application of the solution in the shoot, Assist ${ }^{\circledR}$ mineral oil at $0.5 \% \mathrm{v} / \mathrm{v}$ concentration was added.

When the herbicide was applied to the roots, the experimental units were taken from the tray to remove excess water during two hours. The water in the trays was substituted by the respective herbicide solutions, and the experimental units were again embedded for 24 hours. After this period, the herbicide solutions were removed, and the trays were once again filled with pure water after draining the excess solution. In the treatments applied via the roots, the shoots of the plants, which at the time of application were developed and projected outside the experimental units, had no contact with the solutions. The methodology was improved to simulate field conditions, under which quinclorac is applied only once over the plants, though remaining for a longer period in the water.

At 40 days after emergence (DAE), length, dry and fresh matter of the shoots and roots were evaluated. After shoot and root length was determined, these parts were separated and put into plastic bags, sealed and placed into an expanded polystyrene (Isopor ${ }^{\circledR}$ ) box, containing ice and were transported to the laboratory for fresh matter determination using an analytical scale. The shoots and roots were individually dried in a forced-air circulation oven at $60{ }^{\circ} \mathrm{C}$, until constant mass and dry matter were obtained. Variance analysis was conducted through the $\mathrm{F}$ test at $5 \%$ probability, and, in case of significance, a non-linear regression analysis using the three parameter logistic model was performed.

\section{RESULTS AND DISCUSSION}

Height of the barnyardgrass resistant biotype was not altered at the concentrations evaluated, after application to the shoots and roots (Figure 1). However, the susceptible biotype showed reduction in this variable when the herbicide was applied to the shoot or roots of the plants. This effect increased with increasing quinclorac concentrations. Regarding shoot application, plant height was shorter from $0.5 \mathrm{ppm}$ up to $16 \mathrm{ppm}$ quinclorac concentration, and was maintained approximately constant from 16 to $64 \mathrm{ppm}$. Plant height of the susceptible biotype, at the 16 and $64 \mathrm{ppm}$ concentrations, was around $25 \%$ smaller than the value obtained for the untreated plants (Figure 1A). When quinclorac is applied to the roots, a higher height reduction was observed as herbicide concentration increased, compared to the shoot application, with plant height being around $30 \%$ shorter than the control at $0.5 \mathrm{ppm}$ concentration. From the $16 \mathrm{ppm}$ concentration, the plants were approximately $60 \%$ smaller than the corresponding check (Figure 1B).

Similarly to the shoot, root length was not significantly altered in the barnyardgrass biotype resistant to quinclorac, with values around $18 \mathrm{~cm}$ in the treatments average (Figure 2). However, the susceptible biotype showed shorter roots than the check, after $0.5 \mathrm{ppm}$ of quinclorac concentration, with values around $20 \%$ lower than the susceptible check and the resistant biotype at a higher concentration of 64 ppm (Figure 2A). Root length was more affected by increased quinclorac concentration when applied to the roots than to the shoot of the plants, reaching a reduction around $60 \%$ at $64 \mathrm{ppm}$ of quinclorac concentration, compared to the check, without application (Figure 2B). 
(A)

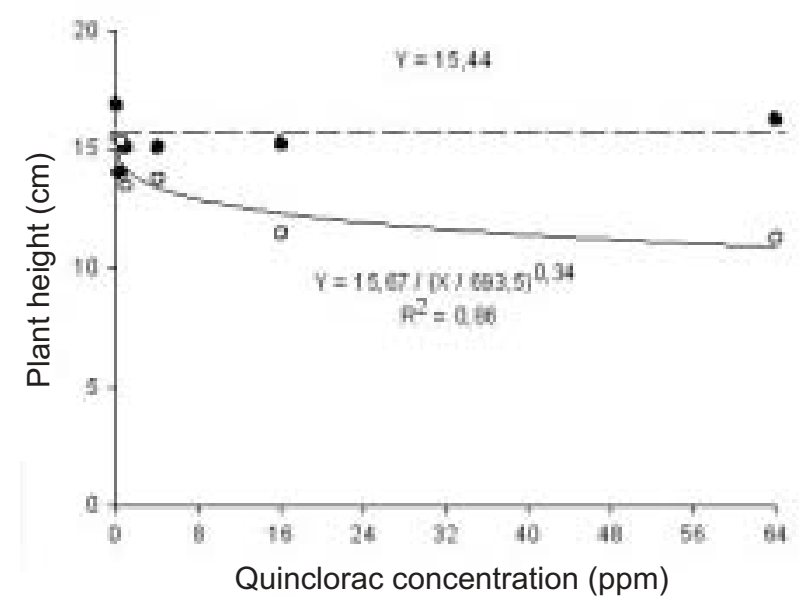

(B)

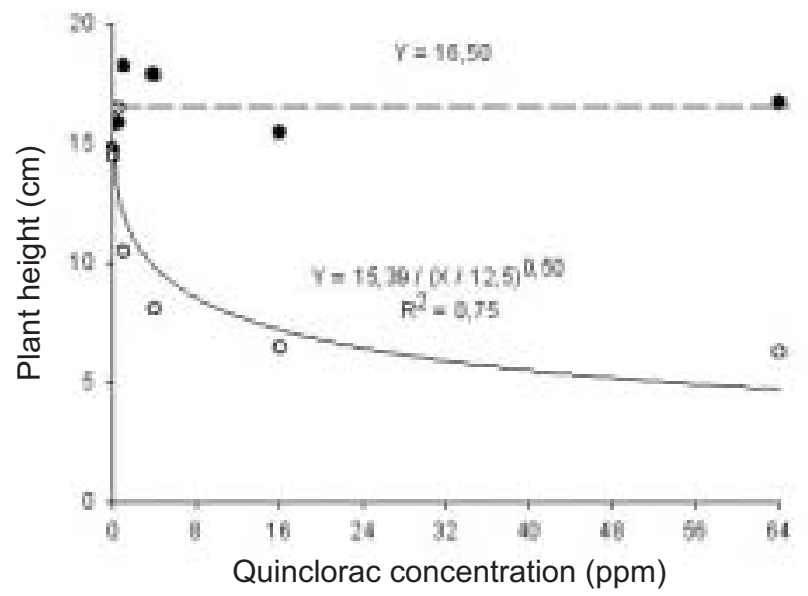

Figure 1 - Height of barnyardgrass plant resistant $(\bullet)$ or susceptible (o) to quinclorac, in function of herbicide application to the shoot $(\mathrm{A})$ or roots $(\mathrm{B})$.

(A)

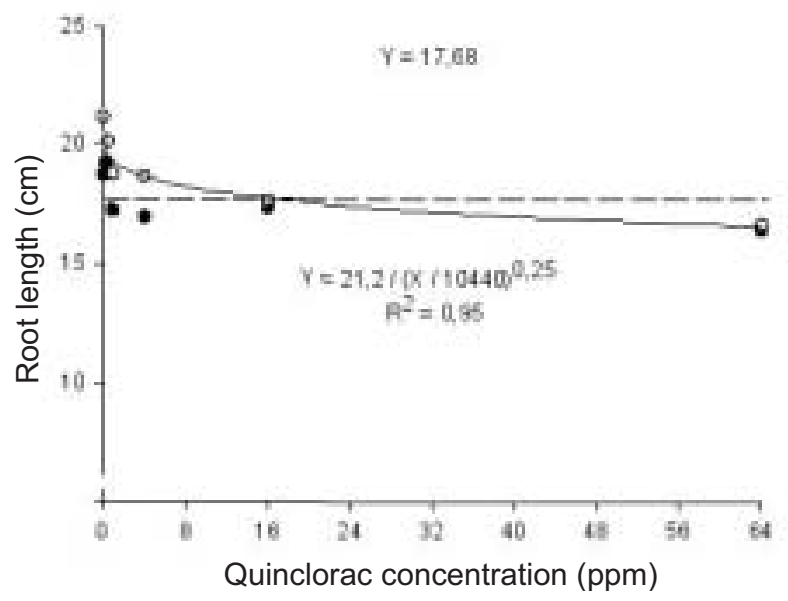

(B)

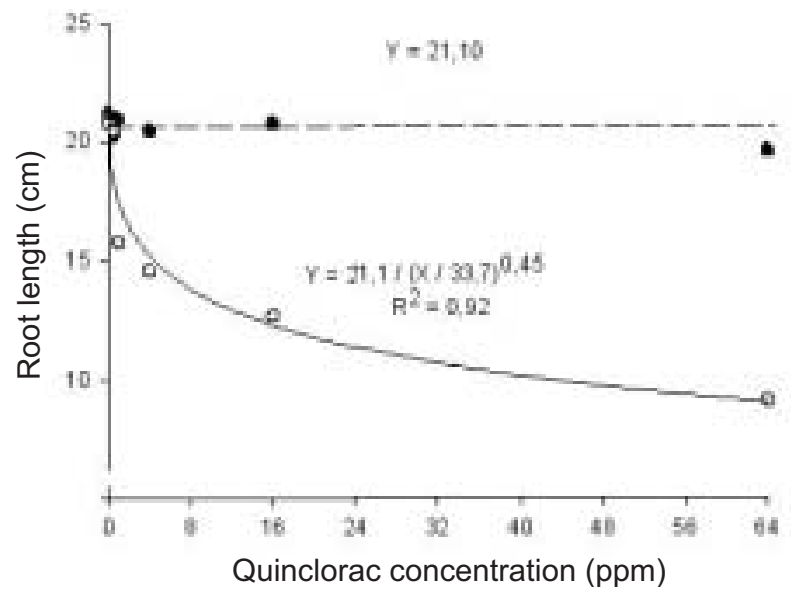

Figure 2 - Root length of barnyardgrass plants resistant $(\bullet)$ or susceptible (o) to quinclorac, in function of herbicide application to the shoot $(\mathrm{A})$ or roots $(\mathrm{B})$

In Digitaria ischaemum, quinclorac application at the dose of $4.480 \mathrm{~g} \mathrm{ha}^{-1}$ resulted in reduced biomass accumulation in the biotype susceptible to this product, as well as in the production of three times more ethylene than that observed in the resistant biotype and cyanide accumulation in the tissues. When cyanide was applied to the resistant biotype as $\mathrm{KCN}$, the results observed between the resistant and susceptible biotypes were similar (Abdallah et al., 2006)
When the KCN is applied to the plants, the ethylene production is increased and the herbicidal mechanism is functional. Similar behavior was observed by Grossmann \& Kwiatkowski (1995). In addition, the pre treatment of the plants of the biotype susceptible to quinclorac with ACC, before herbicide application, resulted in increased tolerance to quinclorac. The application of ACC to the susceptible plants simulated the situation in the resistant biotype where the 
enzyme is functional even under herbicide application. Based on these results, the authors concluded that the mechanism of resistance of $D$. ischaemum to quinclorac is likely due to an altered target site.

The fresh matter of the shoot of the barnyardgrass plants was not altered in the resistant biotype in function of the quinclorac concentrations. However, for the susceptible biotype, fresh matter accumulation in the shoot was lower in function of increased quinclorac doses, with moderate reduction up to the concentration of $4 \mathrm{ppm}$, and more drastic at herbicide concentrations of 16 to $64 \mathrm{ppm}$ (Figure 3). With herbicide application to the shoot of the plants, its fresh matter at the highest quinclorac application was around $50 \%$ smaller than that observed in the check (Figure 3A). However, at the same concentration applied to the roots, shoot fresh matter was close to $15 \%$ of that observed in the corresponding check (Figure 3B) and in the resistant biotype.

In studies involving the level of biotype resistance and the role auxins play in the biosynthesis of ethylene and calcium in mediating resistance, Zheng \& Hall (2001) determined that the mechanism of resistance must be due to an enzymatic alteration in the target site. These authors also identified a group of genes responsible for the codification of these proteins that differed between the resistant and susceptible biotypes. Normally, enzymatic insensitivity to a particular herbicide results in values of $\mathrm{GR}_{50}$ (dose necessary to reduce in $50 \%$ mass accumulation in plants of a particular biotype) and RI (ratio between the $\mathrm{GR}_{50}$ of the resistant and susceptible biotypes) relatively higher than those observed for other resistance mechanisms, such as alterations in the absorption or translocation of the herbicide in the plant, due to the impossibility of connection between the herbicide molecule and the target site (Tranel et al., 2006; Trezzi et al., 2006).

Root fresh matter (Figure 4) was kept stable in function of increased quinclorac concentrations for the resistant biotype. The susceptible biotype presented lower root dry matter with increased quinclorac concentration. Root fresh matter was reduced more drastically after concentration of 4 and
$1 \mathrm{ppm}$ with application to the shoot (Figure 4A) and root system (Figure 4B), respectively. Under application of solution containing $64 \mathrm{ppm}$ of quinclorac, root fresh matter was around 50 and $9 \%$ of that observed in the check, for application to the shoot or roots, respectively.

The behavior of shoot dry matter (Figure 5) was very similar to that of the fresh matter (Figure 3), with the treatments applied to the resistant biotype significantly altering mass accumulation, with mean of $28 \mathrm{mg} \mathrm{plant}^{-1}$ both for the shoot and root applications. At the concentration of $64 \mathrm{ppm}$ of quinclorac, shoot dry matter was around 65 and $18 \%$ of that observed in the untreated plants, for applications on the shoot (Figure 5A) and roots (Figure 5B) of the barnyardgrass plants, respectively.

Root dry matter of the resistant biotype was kept stable in function of quinclorac concentrations, both for the shoot and root applications (Figure 6). For the susceptible biotype, there was a reduction in root dry matter accumulation with increase in quinclorac concentration starting at the smallest dose evaluated $(0.5 \mathrm{ppm})$, regardless of the site of application. At the highest concentration, root dry matter was approximately 65 and $12 \%$ of the value observed in the untreated plants, respectively for quinclorac application on the shoot (Figure 6A) or roots (Figure 6B) of the barnyardgrass plants.

According to Vidal (2002), herbicide absorption via leaves is normally more difficult than via roots, and may be affected by environmental effect on drop, weed density, foliar disposition and surface reached, among other factors. Besides, cuticle presence in the shoot is another barrier the herbicide must overcome for absorption by the plant to occur. In the greenhouse trial, none of these factors was differentiated in the treatments since the leaves were completely covered by the herbicide solution. There was no differential drop formation (cover was continuous), plant density was the same, foliar disposition was not considered because of the mode of application and the surface reached was identical: the entire plant. In the application via roots, these remained in contact with the herbicide solution during a similar period of time. The susceptible barnyardgrass biotype was more affected by quinclorac application to 
the root system (Figures 1B, 2B, 3B, 4B, 5B and $6 \mathrm{~B}$ ), than when applied to the shoot (Figures 1A, 2A, 3A, 4A, 5A and 6A) in all the variables analyzed. Imbibition time could have some influence over these results, even the authors considering that unlikely to happen at considerable amounts.

Due to the non-effect of the quinclorac concentrations on the resistant biotype, it was not possible to determine whether some difference occurred according to importance of each site of application (shoot or roots) between the resistant and susceptible biotypes. However, based on the behavior of the variables studied and as described by Vidal (2002), it is possible to infer that quinclorac can be more efficiently absorbed by the root system than by the shoot of barnyardgrass susceptible to quinclorac, considering that its mobility in the plant may be limited (Scott \& Morris, 1970). Besides, it is possible to state that quinclorac translocation in the susceptible biotype occurs preferentially from the shoot to the roots, and that the roots were more affected than the shoot even in the case of quinclorac application to the shoot of E. crusgalli.
(A)

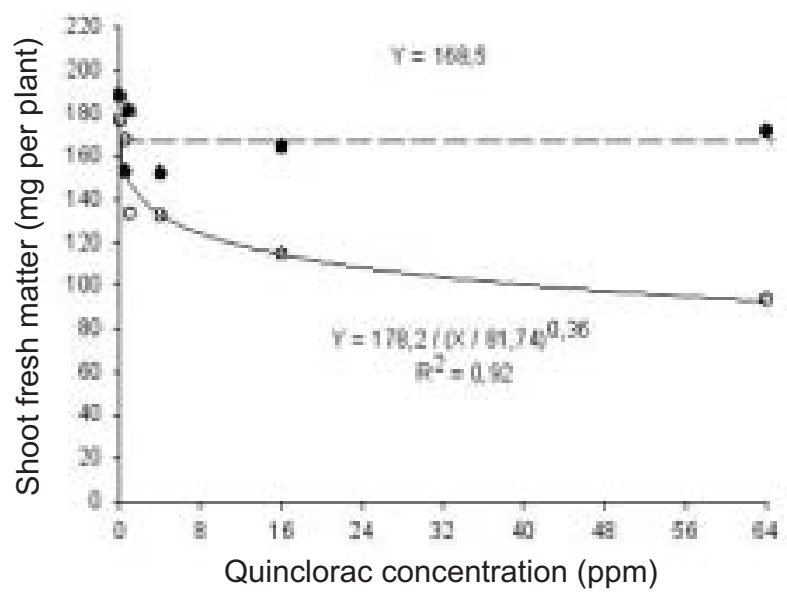

(B)

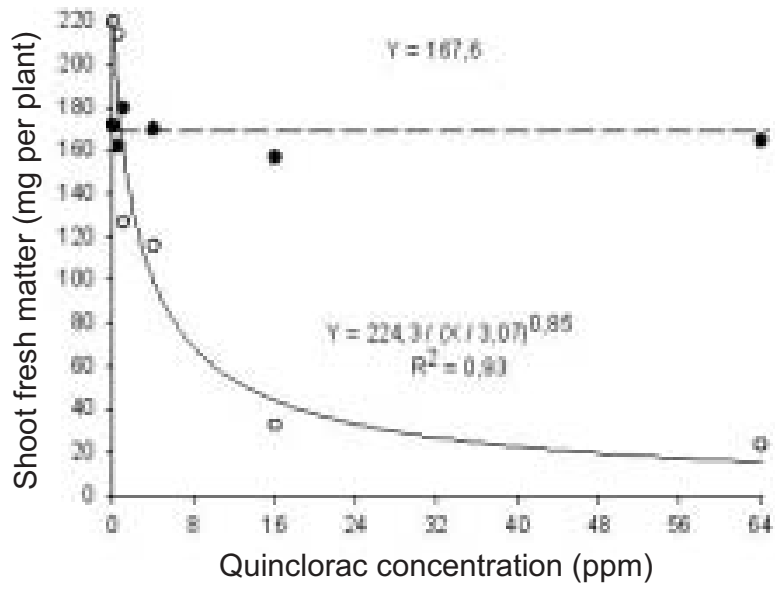

Figure 3 - Shoot fresh matter of barnyardgrass plants resistant ( $)$ or susceptible (o) to quinclorac, in function of herbicide application to the shoot (A) or roots (B).

(A)

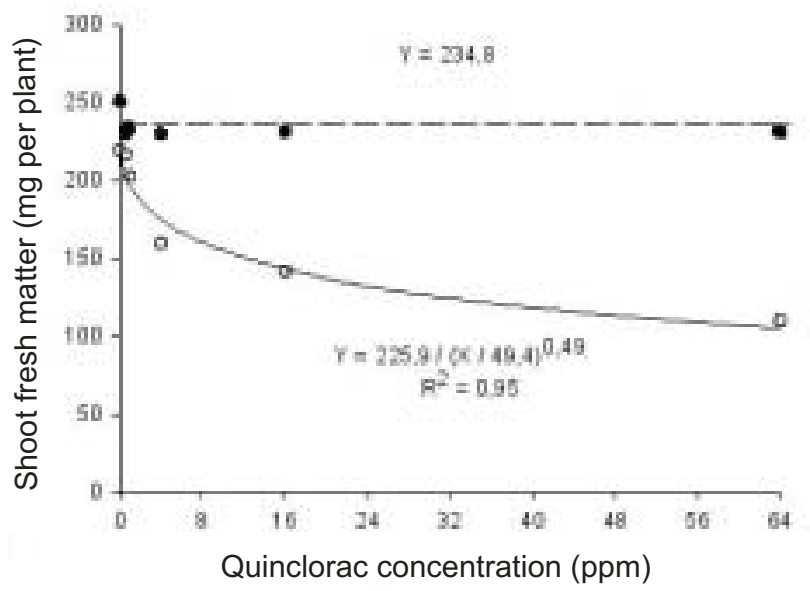

(B)

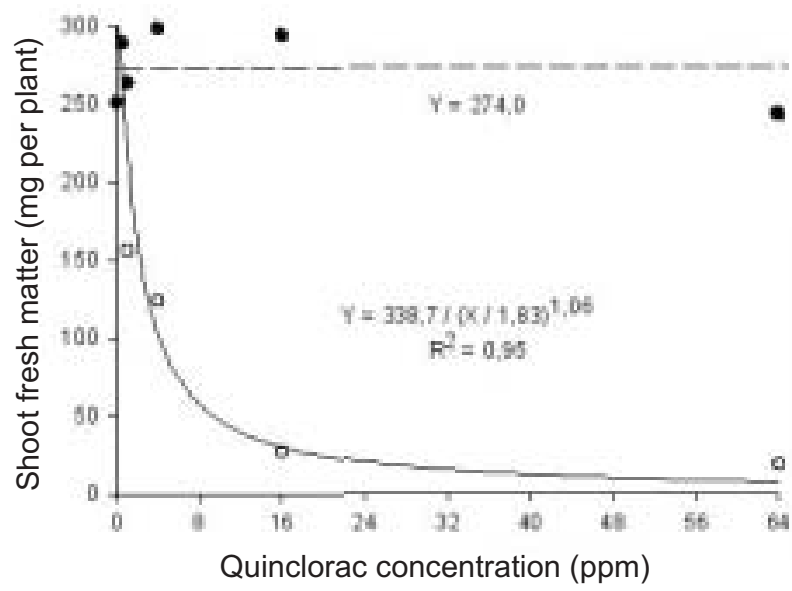

Figure 4 - Root fresh matter of barnyardgrass plants resistant (•) or susceptible (o) to quinclorac, in function of the herbicide application to the shoot (A) or roots (B). 
(A)

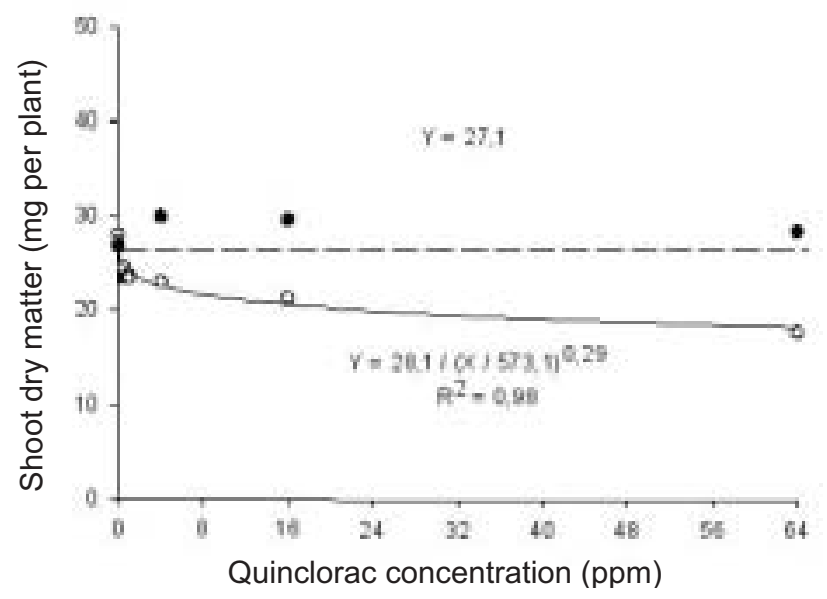

(B)

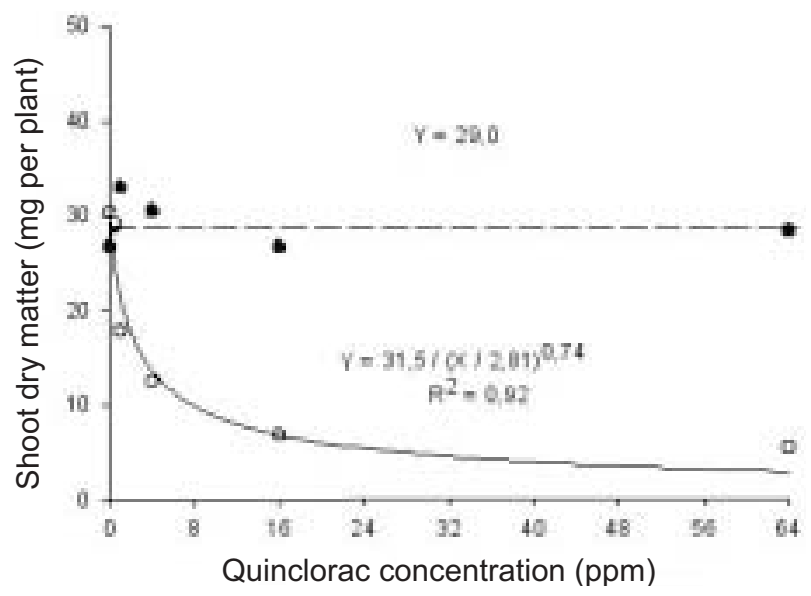

Figure 5 - Shoot dry matter of barnyardgrass plants resistant $(\bullet)$ or susceptible $(\mathbf{0})$ to quinclorac, in function of the herbicide application to the shoot (A) or roots (B).

(A)

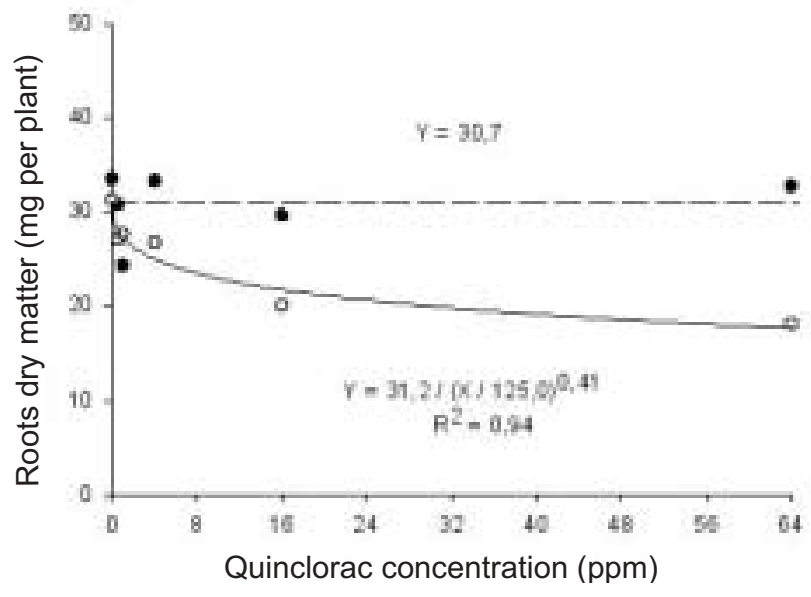

Figure 6 - Root dry matter of barnyardgrass plants resistant application to the shoot $(\mathrm{A})$ or roots $(\mathrm{B})$.

It is also possible to state that the $\mathrm{GR}_{50}$ of the resistant biotype is superior to the susceptible biotype and that the resistance index (RI) is high, since it was above the evaluated interval. Very high RI values were observed in cases where the plant's mechanism of resistance to a particular herbicide is due to some alteration in the target site making it insensitive to the herbicide (Grossmann \& Kwiatkowski, 2000; Tranel et al., 2006; Trezzi et al., 2006). Melo et al. (2003), concluded that the quinclorac
(B)

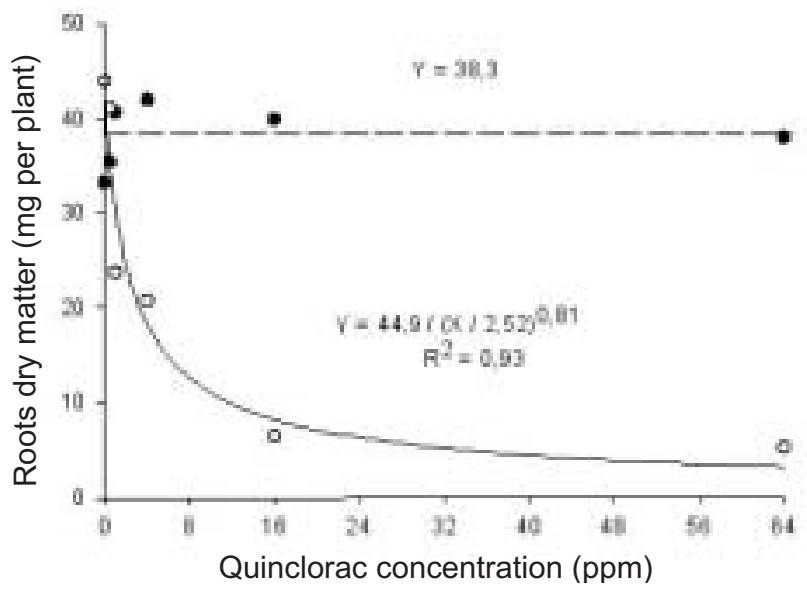

) or susceptible (o) to quinclorac, in function of the herbicide

concentration necessary to reach the $\mathrm{GR}_{50}$ of a particular resistant biotype of Echinochloa crusgalli collected in the southern region of Brazil is approximately 90-fold that of a susceptible biotype $\left(\mathrm{GR}_{50}=90\right)$. On the other hand, lower RI values were related with other mechanisms of action, such as metabolization (Manley et al., 1999) and smaller herbicide translocation in the resistant biotype (Ferreira et al., 2006). However, in function of the high tolerance of the resistant biotype to quinclorac (greater than 128 times the dose 
recommended), it was not possible to determine the dose causing $50 \%$ of dry mass accumulation reduction $\left(\mathrm{GR}_{50}\right)$, nor the resistance index (RI) between both the biotypes.

Quinclorac was more efficiently absorbed by the roots of the susceptible biotype of the barnyardgrass plant than by the shoot system and translocation occurred preferentially in the basipetal direction. Even under high quinclorac concentrations, it was not possible to determine the $\mathrm{GR}_{50}$ of the resistant biotype evaluated, nor the RI between the two biotypes; however, it may be emphasized that the RI is above 128. The results from this research demonstrated that the quinclorac resistance of the evaluated biotype is not due to differences in the absorption site, and strongly suggests that the resistance acquired by the biotype may result from alteration in the target site.

\section{ACKNOWLEDGEMENTS}

We thank CNPq-Brazil for granting the scholarships.

\section{LITERATURE CITED}

ABDALLAH, I. et al. Mechanism of resistance to quinclorac in smooth crabgrass (Digitaria ischaemum). Pest. Biochem. Physiol., v. 84, n. 1, p. 38-48, 2006.

ANDRES, A. et al. Detecção da resistência de capim-arroz (Echinochloa sp.) ao herbicida quinclorac em regiões orizícolas do sul do Brasil. Planta Daninha, v. 25, n. 1, p. 221-226, 2007.

BERGHAUS, R.; WUERZER, B. The mode of action of the new experimental herbicide quinclorac (BAS $514 \mathrm{H}$ ). In: ASIAN PACIFIC WEED SCIENCE CONFERENCE, 11., 1987, Taipei. Proceedings... Taipei: APWSC, 1987. p. 81-87.

CHISM, W. J.; BINGHAM, W.; SHAVER, R. L. Uptake, translocation and metabolism of quinclorac in two grass species. Weed Technol., v. 5, n. 1, p. 771-775, 1991

FERREIRA, E. A. et al. Glyphosate translocation in Italian ryegrass biotypes (Lolium multiflorum). Planta Daninha, v. 24 , n. 2 , p. $365-370,2006$

GROSSMANN, K; KWIATKOWSKI, J. Evidence for a causative role of cyanide, derived from ethylene biosynthesis, in the herbicidal mode of action of quinclorac in barnyard grass. Pest. Biochem. Physiol., v. 51, n. 7, p. 150-160, 1995
GROSSMANN, K.; KWIATKOWSKI, J. The mechanism of quinclorac selectivity in grasses. Pest. Biochem. Physiol., v. 66, n. 1, p. $83-91,2000$.

LÓPEZ-MARTÍNEZ, N.; MARSHALL, G.; DEPRADO, R. Resistance of barnyardgrass (Echinochloa crus-galli) to atrazine and quinclorac. Pest. Sci., v. 51, n. 2, p. 171-175, 1997.

MANLEY, B. S. K.; HATZIOS, K. H.; WILSON, P. Absorption, translocation, and metabolism of chlorimuron and nicosulfuron in imidazolinone-resistant and -susceptible smooth pigweed (Amaranthus hybridus). Weed Technol., v. 13 , n. 4 , p. $759-764,1999$

MELO, P. T. B. S. et al. Determinação de metodologia de laboratório para identificação de sementes de capim-arroz resistente ao herbicida quinclorac. In: CONFERENCIA INTERNACIONAL DE ARROZ DE CLIMA TEMPLADO, 3., 2003, Punta del Este. Anais... Punta Del Este: INIA, 2003 CD-ROM.

SCOTT, P. C.; MORRIS, R. O. Quantitative distribution and metabolism of auxin herbicides in roots. Plant Physiol., v 46, n. 5, p. 680-684, 1970.

SUNOHARA, Y:; MATSUMOTO, H. Comparative physiological effects of quinclorac and auxins, and light involvement in quinclorac-induced chlorosis in corn leaves Pest. Biochem. Physiol., v. 58, n. 1, p. 125-132, 1997.

TRANEL, P. J.; PADZOLDT, W. L.; HAGER, A. G. An altered target site confers resistance to PPO-inhibiting herbicides in a waterhemp biotype. In: ANNUAL MEETING OF THE WEED SCIENCE SOCIETY OF AMERICA, 46., 2006, New York. Abstracts... Champaign: WSSA, 2006. p. 256.

TRESCH, S.; GROSSMANN, K. Quinclorac does not inhibit cellulose (cell wall) biosynthesis in sensitive barnyard grass and maize roots. Pest. Biochem. Physiol., v. 75, n. 1, p. $73-78,2003$

TREZZI, M. M. et al. Bioensaios para identificação de biótipos de Euphorbia heterophylla com resistência múltipla a inibidores da ALS e da PROTOX. Planta Daninha, v. 24, n. 3, p. 563-571, 2006.

VIDAL, R. A. Ação dos herbicidas. Porto Alegre: Artmed, 2002. 89 p

ZAWIERUCHA, J. E.; PENNER, D. Absorption, translocation, metabolism, and spray retention of quinclorac in Digitaria sanguinalis and Eleusine indica. Weed Sci., v. 48 , n. 3, p. 296-301, 2000.

ZHENG, H.; HALL, J. C. Understanding auxinic herbicide resistance in wild mustard: physiological, biochemical, and molecular genetic approaches. Weed Sci., v 49, n. 2 , p. $276-281,2001$ 